Jpn. J. Oral Biol., $32: 289-301,1990$.

\title{
マウス口腔粘膜上皮細胞のケラチンフィラメント
}

\author{
三浦 成 実 武田 正子 \\ 東日本学園大学菌学部口腔解剖学第 2 講座 (主任 : 武田正子教授)
}

〔受付: 平成 2 年 3 月 23 日〕

\section{Keratin filaments in the epithelial cells of mouse oral mucosa}

\author{
Narumi Miura and Masako Takeda \\ Department of Oral Anatomy, School of Dentistry, Higashi Nippon \\ Gakuen University, Tobetsu, Ishikari, Hokkaido, 061-02 \\ (Chief : Prof. Masako Takeda) \\ [Accepted for publication: March 23, 1990]
}

Key words : Keratin filaments/ epithelium/oral mucosa/immunohistochemistry/ electron microscopy

\begin{abstract}
The epithelium of mouse oral mucosa was studied by immunohistochemistry using antikeratin antibodies and electron microscopy. The basal and intermediate layers of the densely cornified epithelium, covering the hard palate, external gingiva, vermilion border of the lip, and the filiform papillae of the tongue, were stained by PKK2 antibody which reacted with 40, 46, 48, and $54 \mathrm{kDa}$ keratin subunits, but not by PKK1 which reacted with $40,45,52.5 \mathrm{kDa}$ keratin subunits. Keratin filaments in these cell layers were arranged in densely aggregated bundles. In the less densely cornified epithelium, covering the soft palate, alveolar mucosa, labial mucosa, gingival sulcus, and interpapillary and ventral portion of the tongue, the basal layer indicated the same staining and ultrastructure as observed in the densely cornified epithelium, furthermore so did all layers of the noncornified junctional epithelium. On the other hand, the intermediate layer of cells of the less densely cornified epithelium were stained by PKK1 antibody, but not by PKK2, and posessed less densely aggregated bundles of filaments or complicated reticulated filaments. These results suggest that the aggregation and distribution pattern of keratin filaments may reflect differences in the keratin subunits which configure the filaments.
\end{abstract}

\section{緒言}

上皮細胞には，直径約 $10 \mathrm{~nm}$ の中間径フィラメ ントが分布しており, 細胞の骨格を構成してい る ${ }^{1-4)}$ 。のフィラメントは, 分子量が40,000から 70,000 (以下 $10^{3}$ を $\mathrm{k}$ とする), 等電点が $\mathrm{pH} 4.5$ 7.5 の約 20 種類のサブュニットからなるケラチン 蛋白を含む ${ }^{51}$ 。種々の上皮細胞には2〜10種類のサ ブュットが含まれている6-9)。このサブニットの種 類は, 単層上皮と重層上皮 ${ }^{101}$, 角化上皮と非角化 上皮の間で違っており, 組織の発生, 分化の過程

（宁061-02）北海道石狩郡当別町字金沢 1757
でも変化す る $^{3,5,7,10-13)}$ 。また角化重層扁平上皮 では，基底層から有棘層，顆粒層さらに角化層 への細胞の分化にともない，含まれるケラチン サブュニットの構成も変化する事が知られてい る $^{10,11,13-16)}$ 。

堘歯類の口腔粘膜の重層扁平上皮は七トと異な り，大部分が角化しているが，角化の程度は部位 によって違っている。近年, 種々の抗ケラチン抗 体を用いた免疫組織化学的方法や, ケラチンの cDNA ブローブを用いて組織切片上でハイリダ イゼーションを行う実験により， 口腔のいろいろ な部位の粘膜上皮のケラチン蛋白に関する報告が なされている ${ }^{17-211}$ 。また, 口腔粘膜上皮の微細構 


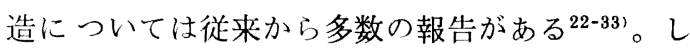
かし，電顕で 観察された各部位のケラチンフィラ メントの像上, 免疫組織化学的方法などで得られ たケラチンサブュニットに関する情報との相互の 関連については全く不明である。そこで今回，マ ウス口腔の種々の部位の粘膜上皮について，ケラ チンに対する 3 種類のモノクロー十ル抗体を用い た免疫組織化学的方法と, 透過電子顕微鏡を 用い た観察により，ケラチンフィラメントの束の形成, 分布状態と, フィラメントを構成するケラチンサ ブュニットとの関連について調べたので報告す る。

\section{材料と方法}

\section{免疫組織化学}

成熟 dd マウスをクロロホルムで麻酔し，舌尖 部, 硬口蓋, 軟口蓋, 臼歯部歯肉, 歯槽粘膜および口 唇粘膜を切り出した。純エタノールで 2 時間固定 し, キシレンで透徹後，パラフィン包埋を行った。
約 $5 \mu \mathrm{m}$ の厚さの切片を脱パラフィン後, 酵素抗 体間接法および PAP 法を DAKO 社製のキッ 卜を用いて行い, 光学顕微鏡で観察した。また, 約 $8 \mu \mathrm{m}$ の厚さの無固定凍結切片を作製し，同様の 方法を行った。対照標本には，正常マウス腹水を 抗ケラチン抗体の代わりに用いて反応させた。

第一抗体に用いたケラチンに対する抗体は, 次 のモノクローナル抗体である。（i ）ブタ腎臟上皮 細胞由来の PKK1抗体 (Labsystems) : 40, 45, $52.5 \mathrm{KD}$ のケラチンサブュニットに反応する。(ii) ブタ腎臟上皮細胞由来の PKK 2抗体 (Labsyste$\mathrm{ms})$ ：40，46，48，54KD のケラチンサブュニッ 卜に反応する。（iii） ヒトの皮膚上皮細胞由来の KL 1抗体 (Immunotech) :56KD のケラチンサ ブュニットに反応する。

\section{電子顕微鏡}

成熟 dd マウスをクロロホルムで麻酔し，左心 室から泠 $2 \%$ グルタールアルデヒド・ $2 \%$ パラホ ルムアルデヒド混合液（カコジル酸ナトリウム緩

Figs. 1-5 Immunoreaction of anti-keratin antibody PKK1 on the epithelium of mouse oral mucosa. Bars indicate the basal lamina (B).

Fig. 1 External gingival epithelium (EG), gingival sulcular epithelium (SE), junctional epithelium $(\mathrm{JE})$, and hard palate $(\mathrm{HP}) . \times 200$.

Fig. 2 Vermilion border of the lip (VB) and labial mucosa (LM). $\times 200$.

Fig. 3 Filiform papilla (FP) and interpapillary epithelium (IP). $\times 200$.

Fig. 4 Soft palate $(\mathrm{SP}), \times 200$.

Fig. 5 Ventral epithelium of the tongue (VE). $\times 200$.

All layers of the epithelia of the external gingiva (Fig. 1. EG), hard palate (Fig. 1. HP), vermilion border of the lip (Fig. 2. VB), and filiform papillae (Fig. 3. FP) lack the staining, whereas the intermediate layer of gingival sulcular epithelium (Fig. 1. SE), labial mucosa epithelium (Fig. 2. LM), interpapillary (Fig. 3. IP) and ventral epithelia (Fig. 5. $\mathrm{VE}$ ) of the tongue, and soft palate epithelium (Fig. 4. SP) is stained. Junctional epithelium is not stained in all layers (Fig. 1. JE).

Figs. 6-10 Immunoreaction of anti-keratin antibody PKK2.

Fig. 6 External gingival epithelium (EG), gingival sulcular epithelium (SE), alveolar mucosa $(\mathrm{AM})$, and junctional epithelium $(\mathrm{JE}) . \quad \times 200$.

Fig. 7 Hard palate (HP). $\times 200$.

Fig. 8 Filiform papilla (AS, PS) and interpapillary epithelium (IP). $\quad \times 200$.

Fig. 9 Soft palate $(\mathrm{SP}), \times 200$.

Fig. 10 Ventral epithelium of the tongue $(\mathrm{VE}) . \times 200$.

Epithelia of the external gingiva (Fig. 6. EG) and hard palate (Fig. 7. HP) are stained in both the basal and intermediate layers, whereas gingival sulcular epithelium (Fig. 6. SE), alveolar mucosa epithelium (Fig. 6. AM), interpapillary (Fig. 8. IP) and ventral (Fig. 10. VE) epithelia of the tongue, and soft palate epithelium (Fig. 9. SP) are stained only in the basal layer. In the intermediate layer of the epithelium of filiform papillae (Fig. 8.), posterior side near the interpapillary portion (PS) and anterior side (AS) are stained. The cornified layer of the anterior side (Fig. 8. arrows) is also stained. All layers of the junctional epithelium (Fig. 6. JE) are stained. 
三浦成実ほか：口腔粘膜上皮細胞のケラチンフィラメント

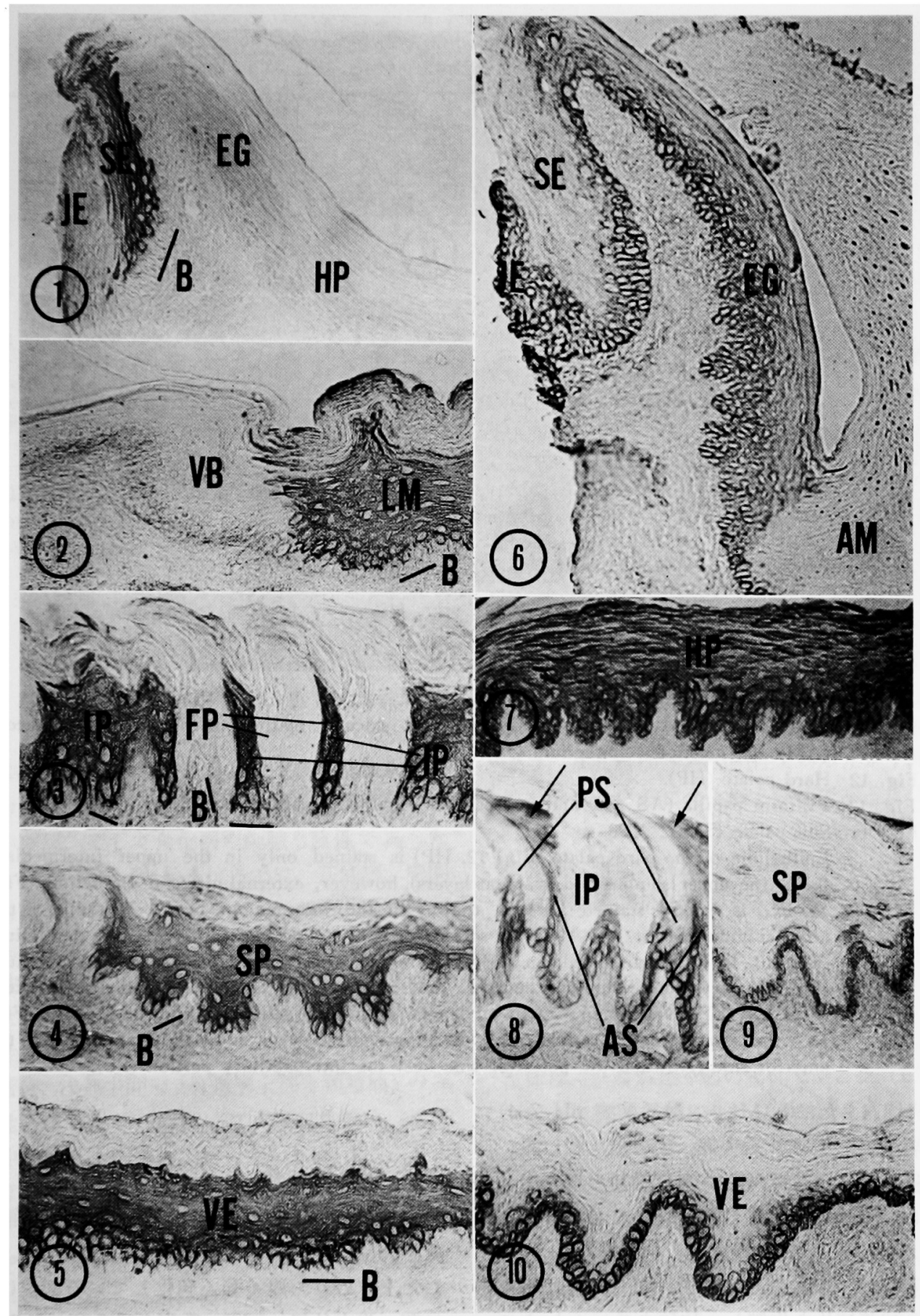




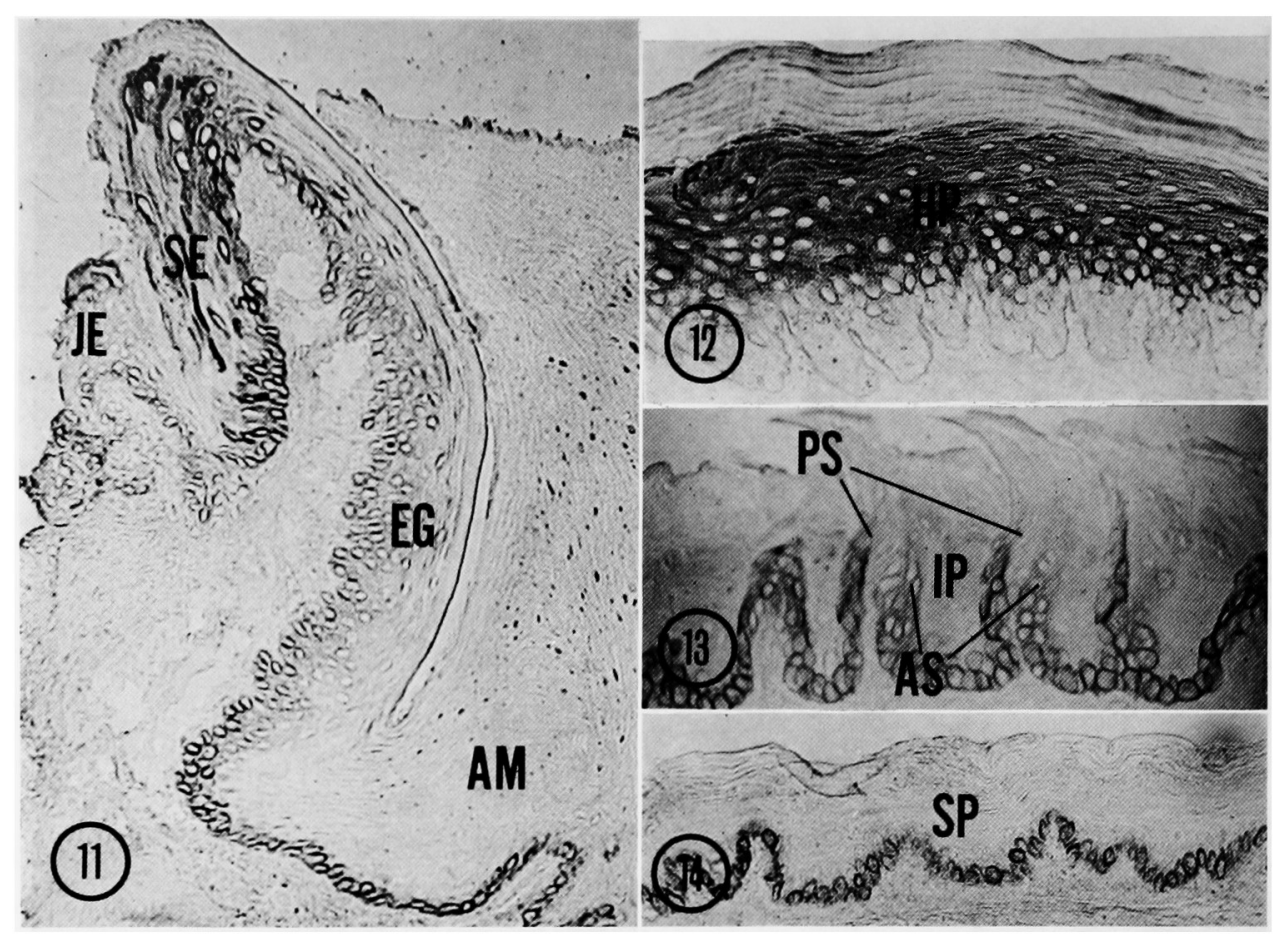

Figs. 11-14 Immunoreaction of anti-keratin antibody KLl.

Fig. 11 External gingival epithelium (EG), gingival sulcular epithelium (SE), alveolar mucosa $(\mathrm{AM})$ and junctional epithelium $(\mathrm{JE}) . \quad \times 200$.

Fig. 12 Hard palate (HP). $\times 200$

Fig. 13 Filiform papilla (AS, PS) and interpapillary epithelium (IP). $\times 200$.

Fig. 14 Soft palate (SP). $\times 200$.

Epithelium of the hard palate (Fig. 12. HP) is stained only in the upper intermediate layer (the upper spinous and granular layers), however, external gingival epithelium (Fig. 11. EG) is weakly stained in both the basal and intermediate layers. Epithelia of the alveolar mucosa (Fig. 11. AM) and soft palate (Fig. 14. SP), and interpapillary epithelium (Fig. 13. IP) are stained only in the basal layer, whereas gingival sulcular epithelium (Fig. 11. SE) is stained in both the basal and intermediate layers. Junctional epithelium (Fig. 11. JE) is weakly stained in all layers. In the epithelium of filiform papillae (Fig. 13.), the basal layer is stained, and the intermediate layer is weakly stained on the anterior side (AS) and the posterior side near the interpapillary portion (PS).

衝液 $\mathrm{pH} 7.4$ または0.1M リン酸緩衝液 $\mathrm{pH} 7.4$ ) により灌流固定した。舌尖部, 硬口蓋, 軟口蓋, 臼歯部歯肉, 歯槽粘膜および口唇粘膜を切り出し て細切し, 上述の固定液で, 一晚, $4^{\circ} \mathrm{C}$ で浸漬固 定した。1\%オスミウム酸（カコジル酸ナトリウ 么緩衝液 $\mathrm{pH}$ 7.4) で， 2 時間， $4^{\circ} \mathrm{C}$ で後固定を 行った。超薄切片を作製し, 酢酸ウラニルとクエ ン酸鉛の二重染色を行い, 透過電子顕微鏡（日立 H-500)で，75KV の加速電圧により観察した。

\section{結果}

\section{(1) 免疫組織化学}

マウスの口腔粘膜上皮は, 角化層が厚い部位と, 薄い部位，さらに非角化部位に分けられる。観察 した上皮のうち厚く強く角化している部位は, 硬 口蓋, 歯肉外縁, 紅唇, 舌背糸状乳頭の各上皮で, 薄く弱く角化しているのは軟口蓋，歯槽粘膜，口 唇粘膜, 歯肉溝, 舌下面, 舌背糸状乳頭間の各上 皮である。そして, 非角化部位は歯肉付着上皮で ある。 
Table-1 Reactivity of antikeratin antibodies and aggregation pattern of keratin filament bundles in the epithelial cells of mice.

\begin{tabular}{|c|c|c|c|c|c|c|c|c|c|}
\hline & \multirow{2}{*}{\multicolumn{2}{|c|}{$\begin{array}{l}\text { densely } \\
\text { cornified } \\
\text { epithelia }\end{array}$}} & \multirow{2}{*}{\multicolumn{2}{|c|}{$\begin{array}{l}\text { less densely } \\
\text { cornified } \\
\text { epithelia }\end{array}$}} & \multicolumn{4}{|c|}{ filiform papilla } & \multirow{3}{*}{$\begin{array}{r}\begin{array}{l}\text { Junctional } \\
\text { epithelium }\end{array} \\
\text { all layers }\end{array}$} \\
\hline & & & & & \multicolumn{2}{|c|}{ anterior } & \multicolumn{2}{|c|}{ posterior } & \\
\hline & B.L. & I.L. & B.L. & I.L. & B.L. & I.L. & B.L. & I.L. & \\
\hline $\begin{array}{l}\text { PKK } 1 \\
(40,45,52.5 \mathrm{KD})\end{array}$ & - & - & - & + & - & - & - & - & - \\
\hline $\begin{array}{l}\text { PKK } 2 \\
(40,46,48,54 \mathrm{KD})\end{array}$ & + & + & + & - & + & + & + & - or $+^{* 2}$ & + \\
\hline $\mathrm{KL} 1(56 \mathrm{KD})$ & -or \pm & tort & + & $-*_{1}$ & + & \pm & + & - or $+{ }^{* 3}$ & \pm \\
\hline $\begin{array}{l}\text { aggregation pattern } \\
\text { of keratin filament } \\
\text { bundles }\end{array}$ & dense & dense & dense & loose & dense & dense & dense & dense & dense \\
\hline
\end{tabular}

+ : positive reaction \pm : slightly positive reaction - : negative reaction

B.L.: basal layer I.L.: intermediate layer

densely cornified epithelia : hard palate, gingiva, and vermilion border of the lip.

less densely cornified epithelia : soft palate, alveolar mucosa, labial mucosa, dorsal interpapillary and ventral epithelia of the tongue, and sulcular epithelium.

$*_{1}$ : Sulcular epithelium is stained.

$*_{2,3}$ : The cells near the interpapillary portion are stained, and those near the anterior portion are not stained.

a . 硬口蓋, 歯肉外縁, 紅唇, 舌背系状乳頭 の 上皮

PKK 1抗体により，これらの上皮の基底層の細 胞はすべて陰性を示し, さらに有棘層と顆粒層を 含む中間層, そして角化層の細胞も陰性であった (Fig. 1，2，3)。PKK 2抗体では, 基底層, 中間 層ともにすべて陽性を示した。しかし, 手状乳頭 の後面部では, 前面部に近い前方の部位が中間層 で陰性となった。また, 角化層は, 寸べて陰性で あったが，アルコール固定の 采状乳頭前面部のみ が陽性となった（Fig. 6，7，8）。KL 1 抗体には， 硬口蓋は, 浅部中間層 (有棘層上部と顆粒層)のみ が陽性を示したが (Fig. 12), 歯肉外縁は, 基底 層, 中間層とも弱陽性であった (Fig. 11)。系状 乳頭は PKK 2抗体と似た反応を示し，基底層は 陽性, 中間層は後面部の前方の陰性部分を除いて 陽性を示し, 角化層は, アルコール固定で前面部 のみが陽性を示したが，他は陰性であった（Fig. 13)。

b . 軟口蓋, 歯槽粘膜, 口唇粘膜, 歯肉溝, 舌 下面, 舌背系状乳頭間の上皮

PKK 1抗体により，これらの上皮の基底層はす べて陰性であったが，中間層は硬口蓋などの角化
の強い上皮と違って，陽性を示した。角化層は陰 性であった（Fig. 1，2，3，4，5）。PKK 2抗体 では，基底層はすべて陽性であったが中間層で陰 性を示し, さらに角化層も陰性であった(Fig. 6, $8,9 ， 10)$ 。 $\mathrm{KL} \mathrm{1}$ 1抗体は, 基底層はすべて陽性, 中間層は，歯肉溝上皮のみが陽性で，その他の上 皮は PKK 2抗体と同じく陰性で，角化層はすべ て陰性であった（Fig. 11，12，14）。

c。付着上皮

PKK 1抗体では，全層が陰性（Fig，1)，PKK 2抗体では全層が陽性を示した（Fig．6）。KL 1 抗体は，全層がごく弱い陽性であった（Fig. 11）。

以上の結果をまとめたものが，TABLE-1であ るが，基底層はすべての部位の上皮で, PKK 1抗 体陰性, PKK 2抗体陽性であったが, 中間層で は，角化の強い上皮群では PKK 1 抗体陰性，2 PKK 2抗体陽性，角化の弱い上皮群では，PKK 1 抗体陽性, PKK 2抗体陰性で, 丁度逆の反応 を示した。非角化上皮の付着上皮は PKK 1,PKK 2 両抗体に対して，角化の強い上皮群と同じ反応 を示した。 KL 1抗体は，部位により様々な反応 を示した。

（2）電子顕微鏡 


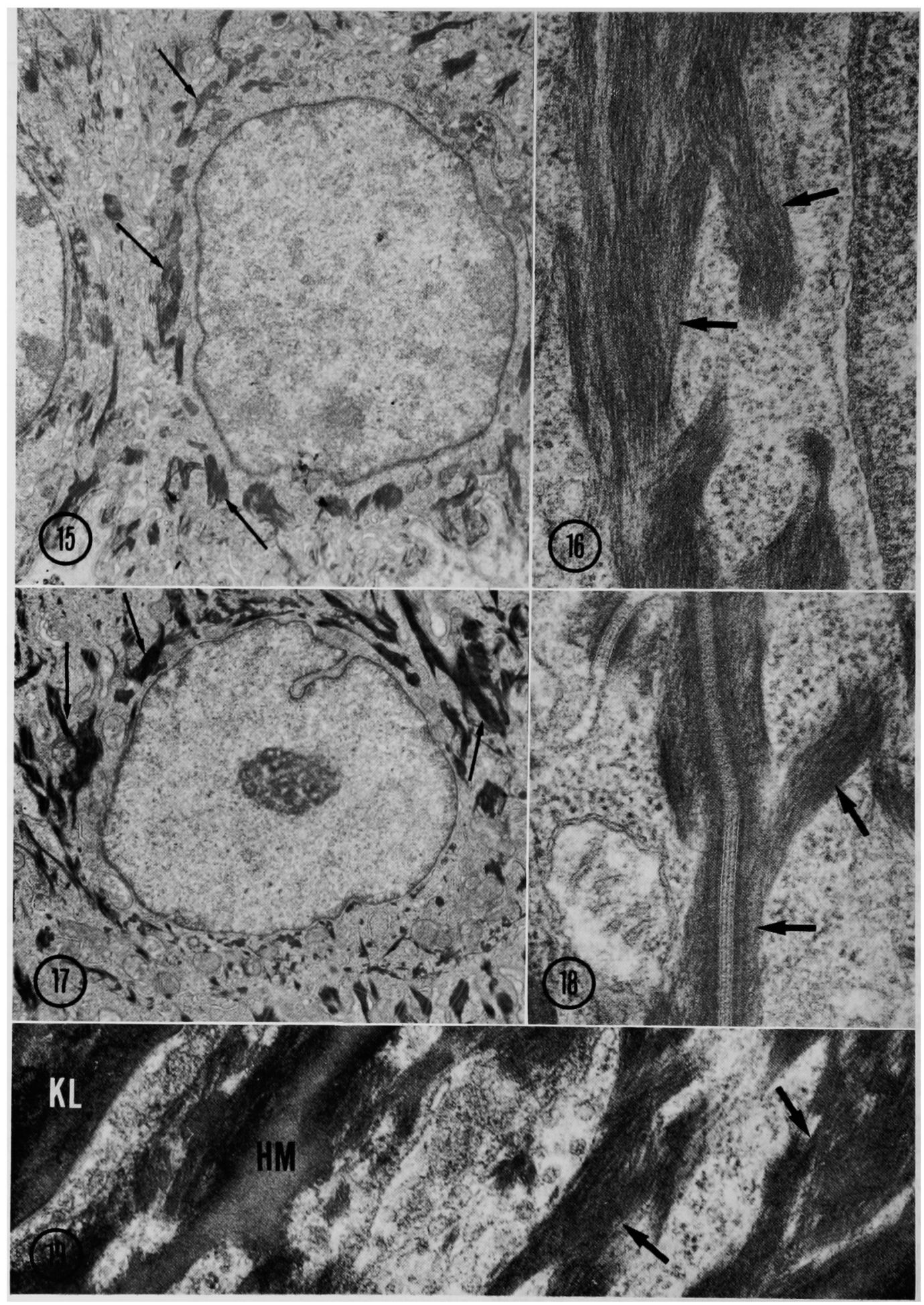



上皮

a . 硬口蓋, 歯肉外縁, 紅唇, 舌背系状乳頭の

基底層では, どの部分の上皮の細胞も胞体のト ノフィラメントが集合し, 電子密度の高い稠密な 束を形成していた，デスモゾームに付着するフィ ラメント束は, 核をとりまいて走る束に集合して いた。大部分の束は胞体長軸に平行に, すなわち 基底膜に対して垂直な 方向に走っていた（Fig.

15，16）。深部中間層（有棘層）になると，フィラ メントはさらに密に集合し, 高電子密度の太い束 を作っていた (Fig. 17，18)。浅部中間層（顆粒 層) では, 硬口蓋, 歯肉外縁で, 稠密なフィラメ ント束の中に時折高電子密度の均質な物質が見ら れ, 角化層になると, この均質な物質が胞体全体 を埋めていた (Fig. 19)。糸状乳頭前面部の浅部 中間層には二相性のケラトヒアリン顆粒がみら れ, 比較的高電子密度のフィラメント束がこの顆 粒に付着していた。この部位のフィラメント束の 中には硬口蓋などに見られるような高電子密度の 均質な物質は認められなかった (Fig. 20)。一方, 釆状乳頭後面部の浅部中間層では，フィラメント 束全体を覆うように高電子密度の均質な物質が見 られ，個々のフィラメントはその中に埋め込まれ ているような形で存在していた。そして，フィラ メントを埋め込んでいる均質な物質の周辺部に は, 球形のさらに高電子密度の部分が数個付着し ていた。なお，この部位にはケラトヒアリン顆粒 は認められなかった（Fig. 21）。

b . 軟口蓋, 歯槽粘膜, 口唇粘膜, 歯肉瑇, 舌 下面, 舌背系状乳頭間の上皮

基底層はすべて，硬口蓋などの角化の強い上皮 と同じで，胞体のトノフィラメントは高電子密度 の椆密な束を作っていた（Fig. 23)。中間層では， 密に集合していたフィラメント束がほどけてきて
表層に近づくにつれて短い低電子密度の緩い，細 い束となり，さらにばらばらになったフィラメン トが網状に交錯していた（Fig．22，24，25）。 c. 付着上皮

硬口蓋などの角化の強い上皮と似ており，基底 層から表層の細胞まですべて, 胞体のフィラメン 卜は高電子密度の 稠密な束を作っていた（Fig. $26,27)$ 。

\section{考察}

今回の実験では，観察した全ての部位の上皮の 基底層は，フィラメントが稠密な束を作り，PKK 1 抗体に対して陰性，PKK 2抗体陽性を示した。 一方, 中間層は, 角化の強い上皮と弱い上皮との 間で，フィラメントの集合状態が異なり，抗ヶラ チン抗体に対しても異なる反応を示した。すなわ ち，角化の強い上皮では，稠密なフィラメントの 束を持ち，基底層と同様，PKK 1抗体陰性, PKK 2 抗体陽性を示し, 角化が弱く, 電子密度の低い緩 い束あるいはばらばらに錯走するフィラメントを 持つ上皮は反対に, PKK 1抗体陽性, PKK 2抗体 陰性となった。また非角化上皮の付着上皮の全層 は，角化の強い上皮と同じく，フィラメントの束 が密に集合し，PKK 1抗体陰性，PKK 2抗体陽 性となった。硬口蓋などの角化の強い上皮は機械 的刺激に対して抵抗性を保持しなければならない 部位であるが，付着上皮も，たえず細菌などの感 染にさらされ，上皮細胞間には好中球，単球が侵 入し, 次第に歯, 歯肉境が根尖侧へ 移動すること などに対して抗しなければならない部位である。 舌有郭乳頭の溝に面する上皮も非角化上皮である が，全層の細胞が稠密なフィラメント束を持ち， PKK 1抗体陰性，PKK 2抗体陽性を示すが，こ の部分の上皮細胞は，ここに多数存在する味蕾

Fig. 15-16 A basal cell of the external gingival epithelium contains densely aggregated bundles of filaments (arrows) which are associated with the desmosomes. Fig. 15. $\times 9,000$. Fig. 16. $\times$ 60,000 .

Fig. 17-18 Lower intermediate layer of the epithelium of the hard palate. Filaments (arrows) aggregate densely and terminate at the large desmosomes. Fig. 17. $\times 9,000$. Fig. $18 . \times 60,000$.

Fig. 19 Upper intermediate and keratinized layers of the hard palate. In the upper intermediate layer, the dense homogeneous material (HM) often fills the spaces between the filaments. Filaments (arrows) are tightly packed, so it is difficult to distinguish individual filaments. In the keratinized layer (KL), the homogeneous material fills in the cell. $\times 60,000$. 


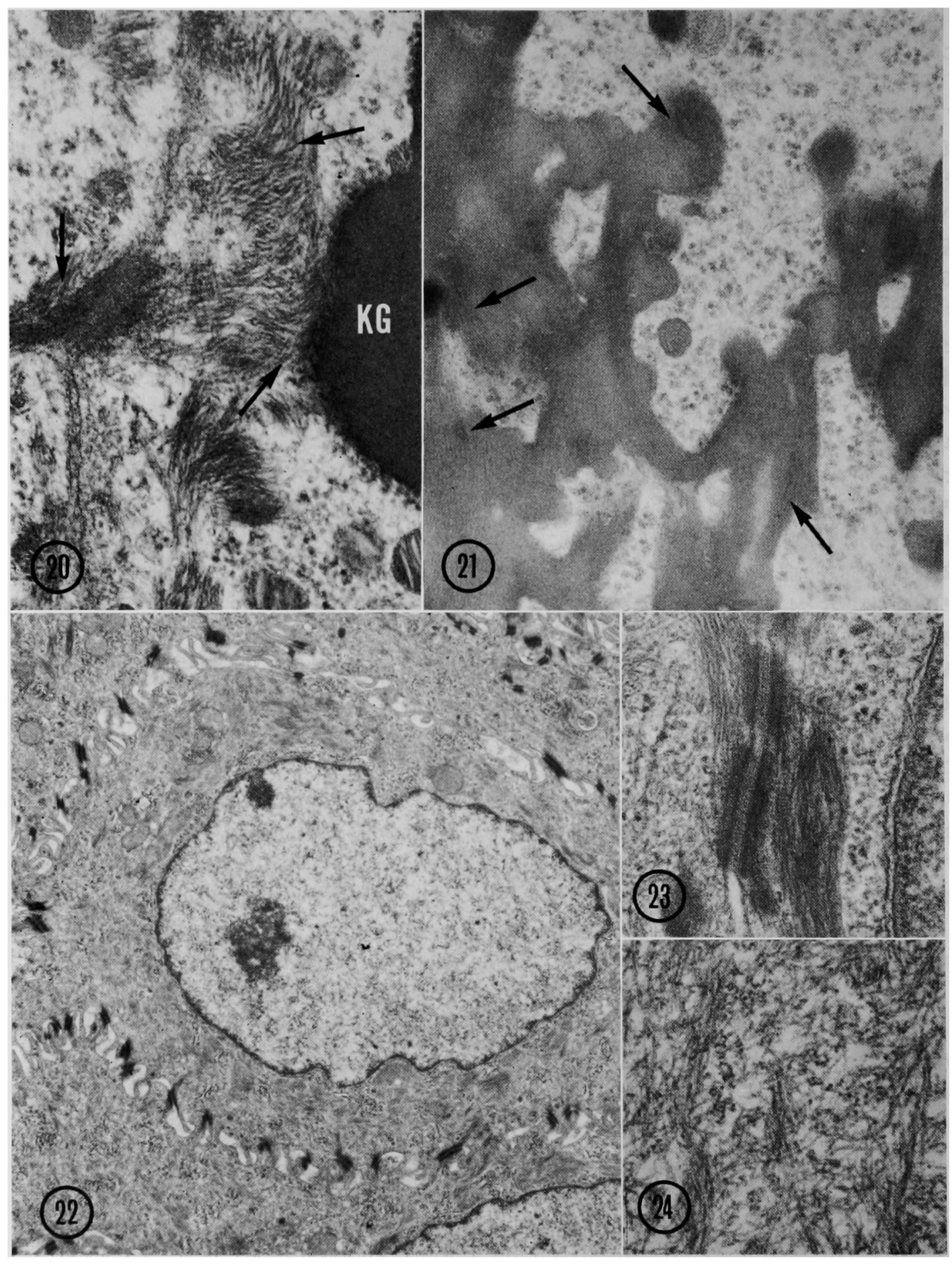


を周りから支持する機能を負っている場所であ $3^{34-36)}$ 。他に 比較的稠密に集合するフィラメン トの束は，八ムスターやラットの 系状乳頭， ラ ットの硬口蓋，ヒトの皮膚などの上皮細胞にも 見られるが，ここは厚い角化層を持つ上皮であ

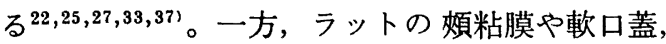

舌釆状乳頭間上皮は薄い角化層を 持つ上皮である が，その中間層の細胞のフィラメントは，ばらば らになって網状に分布する ${ }^{23,25,30,33) 。 す な わ ち, ~}$

機械的強度が必要な場所の上皮細胞のケラチンフ イラメントは, 稠密な束を作るといえる。そして， その場合，マウス口腔粘膜では，フィラメントを 構成する ケラチン蛋白は, PKK 2抗体陽性, PKK 1 抗体陰性であった。細胞に加わる力を放散させ てクッションの役目をしたり，伸びに対する可動 性が必要な上皮のフィラメントは, 胞体全体に充 満する緩い束を作り，あるいは，ばらばらになっ て網状に錯走し，そして PKK 1抗体陽性, PKK 2 抗体陰性となった。以上のことから，フィラメ ントの集合, 分布の状態は, フィラメントを構成 するケラチンサブュニットの違いを反映するもの と考えられる。

舌の釆状乳頭は, 特殊な 分化を示し, 構造上前 面部と後面部に分けられる ${ }^{25,27,33,38)}$ 。Rentrop ら は19)，ケラチンの cDNA を用いた in situ ハイ ブリダイゼーション法により，マウス舌上皮の全 ての基底細胞は， $52 \mathrm{kD}$ ケラチンを含むが，基底 層以外の細胞は, 部位により含まれるケラチンの
サブユニットが異なることを示した。すなわち， 中間層では，舌下面と乳頭間上皮は $57 \mathrm{kD}$ と $42 \mathrm{kD}$, 系状乳頭前面部は $47 \mathrm{kD}$, 後面部は $59 \mathrm{kD}$ のケラチ ンを含んでいると報告している。われわれの実験 でも同様に，糸状乳頭，乳頭間および 下面の上皮 の基底層は，すべて一様に PKK 2抗体陽性であ ったが，中閒層では部位により抗ケラチン抗体に 対する反応が異なっていた。乳頭間と下面の上皮 は PKK 1抗体陽性, 系状乳頭前面部は PKK 2 抗体陽性, 後面部は他の部分とは異なり, 高電子 密度の均質な柱状物質中にフィラメントが埋め込 まれておうり，PKK 1，PKK 2抗体ともに陰性で あった。後面部のうちでも乳頭間上皮側の後部で は，稠密なフィラメント束を持ち，PKK 2抗体 陽性であったが，この部位は，系状乳頭を後面か ら支えると外鞘として機械的支持の 役割を果たす ものと思われる ${ }^{33}$ 。

一方，KL 1抗体について見ると，フィラメン トが密に集合する基底層でも，陽性と陰性を示す 部位があり，フィラメントの集合，分布状態と KL 1抗体の反応との間には一定の関係が見いだ されなかった。すなわち, 多様なケラチンサブュ ニットが，上皮の置かれた微妙な環境の 差異に応 じて含まれるものと考えられる。しかし，多数の ケラチンサブュニットの中でも, PKK 1抗体ある いは PKK 2抗体に反応するサブュニットは，フ イラメントの集合，分布の状態を決める要因の一 つになるのではないかと思われる。

Fig. 20 Upper intermediate layer on the anterior side of the filiform papilla. Relatively high electrondense bundles of filaments (arrows) are associated with the keratohyaline granule (KG). $\times 60,000$.

Fig. 21 Upper intermediate layer on the posterior side of the filiform papilla. The bundles of filaments are filled up with the dense homogeneous material (arrows). $\times 60,000$.

Fig. 22 Lower intermediate layer of the soft palate. The bundles of filaments densely aggregated in the basal layer become more loose, thinner, and shorter, and are reduced in electron-density. $\times 60,000$.

Fig. 23 Basal layer of the soft palate. The cytoplasmic filaments form densely aggregated bundles. $\times 60,000$.

Fig. 24 Upper intermediate layer of the soft palate. Filaments in the cells form the reticular network. $\times 60,000$.

Fig. 25 Intermediate layer at the boundary between the interpapillary epithelium and posterior side of the filiform papilla. Note the densely aggregated bundles of filaments in the epithelial cells of the posterior side of the papilla (arrows) and the complicated reticulated filaments in the interpapillary epithelial cells (arrowheads). $\times 60,000$.

Figs. 26-27 Junctional epithelium. Filaments, in all layers, form the densely aggregated bundles (arrows). Fig. $26 \times 9,000$. Fig. $27 \times 60,000$. 


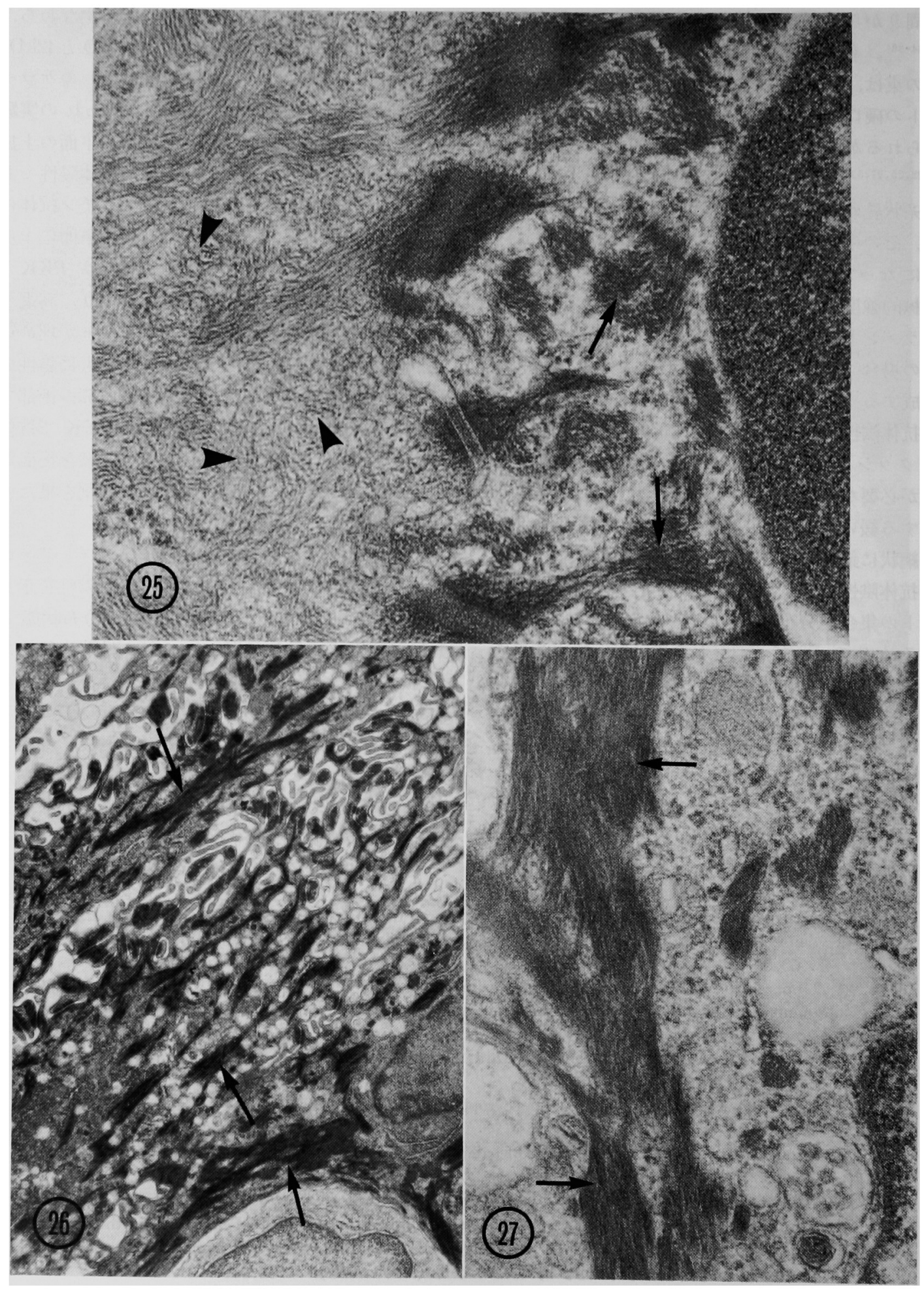


上皮細胞に含まれる ケラチン蛋白は, 分子量が 比較的小さい酸性の グループ $(40-56.5 \mathrm{kD}$, タイ プI）と，分子量が比較的大きい塩基性のグルー プ (52-67kD，タイプ II )とに分けられる。この各 グループから参加したサブユニットが対になっ て, より合わさって $2 \sim 3 \mathrm{~nm}$ のプロトフィラメ ントを作り，それがいくつかより合わさって 4.5 $\mathrm{nm}$ のプロトフィブリルとなり，さらにそれが集

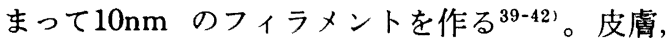

角膜, 食道などの上皮細胞には, それぞれ特徵的 なサブュニットの組み合わせが含まれていること が報告されている9'。

ケラチン蛋白分子の中心は， $\alpha$ らせん部分で, このアミノ酸配列の違いにより，タイプI とタイ プII゙決定され，両端のランダム部分は，細胞や 組織の分化により差がある。10nm フィラメント の芯の部分は $\alpha$ らせん部分からなり，両端のラ ンダム部分は, フィラメントの表面に突き出すと 考えられている6,42,43)。したがって,このランダム 部分の構造が，細胞や組織によって異なるフィラ メントの束の形成や，分布状態を 規制するのでは ないかと推測される ${ }^{42,43)}$ 。その他に，ヶラチンフ イラメント関連蛋白質の存在が想定されるが，現 在, 角化層に存在する filaggrin 以外の関連蛋白 質についてはまだ知られていない44)。

\section{結 論}

マウスの口腔粘膜上皮について，抗ケラチン抗
体（PKK 1抗体，PKK 2抗体）を用いた免疫組 織化学と, 透過電子顕微鏡により検索した。

1. 角化の強い上皮群（硬口蓋,歯肉外縁, 紅唇, 舌背系状乳頭の上皮）は，基底層, 中間層ともに， 高電子密度の稠密なケラチンフィラメントの束が 分布し, PKK 1抗体に対して陰性, PKK 2抗体 に陽性を示した。

2. 角化の弱い上皮群 (㳄口蓋, 歯槽粘膜, 口唇 粘膜, 歯肉溝, 舌下面, 舌背系状乳頭間の上皮) は，基底層は稠密なケラチンフィラメント束が分 布し, PKK 1抗体陰性, PKK 2抗体陽性であっ たが，中間層になると，フィラメントの束はほど けてきて,ばらばらになって錯走し，PKK 1抗 体陽性, PKK 2抗体陰性となった。

3. 非角化上皮である付着上皮は, 角化の強い上 皮群之同様, 全層の細胞のヶラチンフィラメント は稠密な束を作り，PKK 1抗体陰性，PKK 2抗 体陽性であった。

4. 以上より,ケラチンフィラメントが稠密な束 を作る上皮細胞は，PKK 1抗体陰性，PKK 2抗 体陽性を示し, 反対に, フィラメントが緩い束を 作り，あるいはばらばらになった細胞は，PKK1 抗体陽性，PKK 2抗体陰性を示した。のことか ら，ケラチンフィラメントの束の形成，分布の状 態は, フィラメントを構成するケラチン蛋白のサ ブユニットの違いを反映するものと思われる。

抄録：マウスの口腔粘膜上皮について, 抗ケラチン抗体を用いた免疫組織化学と，電子顕微鏡により検索 した。硬口蓋, 歯肉外䋑, 紅唇, 舌背系状乳頭などの角化の強い上皮群は, 基底層, 中間層とともに, PKK 1 (40，45，52.5kD のケラチンサブュニットに反応）に陰性，PKK 2抗体（40，46，48，54kD のサブュニ ットに反応）に陽性を示し，ケラチンフィラメントは稠密な束を作って分布していた。軟口蓋，歯櫣粘膜， 口唇粘膜, 歯肉溝, 舌下面および舌系状乳頭間などの角化の弱い上皮群の基底層も同様の所見を示し, さら に非角化上皮である付着上皮の全層も同様であった。一方，角化の弱い上皮群の中間層は，PKK 1 抗体陽 性, PKK 2抗体陰性を示し, フィラメントの束は緩く, あるいは, ばらばらになり, 網状にほどけて分布し ていた。このことから, ケラチンフィラメントの束の作成, 分布の状態は, フィラメントを構成するケラチ ン蛋白のサブユニットの違いを反映するものと思われる。

\section{文軒}

1) Franke, W. W., Weber, K., Osborn, M., Schmid, E. and Freudenstein, C. : Antibody to prekeratin: Decoration of tonofilament-like arrays in various cells of epithelial character. Exp. Cell Res. 116:429-455, 1978.

2) Schlegel, R., Banks-Schlegel, S. and Pinkus, 
G. S. : Immunocytochemical localization of keratin in normal human tissues. Lab. Invest. 42 : 91-96, 1980.

3) Franke, W. W., Denk, H., Kalt, R. and Schmid, E.: Biochemical and immunological identification of cytokeratin proteins present in hepatocytes of mammalian liver tissue. Exp. Cell Res. 131 : 299-318, 1981.

4) Denk, H., Krepler, R., Lackinger, E., Artlieb, U. and Franke, W. W.: Biochemical and immunocytochemical analysis of the intermediate filament cytoskeleton in human hepatocellular carcinomas and in hepatic neoplastic nodules of mice. Lab. Invest. 46 : 584-596, 1982.

5) Moll, R., Franke, W. W., Schiller, D. L., Geiger, B. and Krepler, R. : The catalog of human cytokeratins: Patterns of expression in nomal epithelia, tumors and cultured cells. Cell 31 : 11-24, 1982.

6) Eichner, R., Rew, P., Engel, A. and Aebi, U.: Human epidermal keratin filaments: Studies on their structure and assembly. Ann. N. Y. Acad. Sci. 455 : 381-402, 1985.

7) Quinlan, R. A., Schiller, D. L., Hatzfeld, M., Achstatter, T., Moll, R., Jorcano, J. L., Magin, T. M. and Franke, W. W. : Patterns of expression and organization of cytokeratin intermediate filaments. Ann. N. Y. Acad. Sci. 455 : 282-306, 1985.

8) Sun, T. -T., Tseng, S. C. G., Huang, A. J. -W., Cooper, D. and Eichner, R. : Monoclonal antibody studies of mammalian epithelial keratins: A review. Ann. N. Y. Acad. Sci. 455 : 307-329, 1985.

9) Eichner, R., Sun, T. -T. and Aebi, U. : The role of keratin subfamilies and keratin pairs in the formation of human epidermal intermediate filaments. J. Cell Biol. 102 : 1767-1777, 1986

10) Lane, E. B., Bartek, J., Purkis, P. E. and Leigh, I. M. : Keratin antigens in differentiating skin. Ann. N. Y. Acad. Sci. 455 : 241-258, 1985.

11) Banks-Schlegel, S. P.: Keratin alterations during embryonic epidermal differentiation: A prestage of adult epidermal maturation. J. Cell Biol. 93 : 551-559, 1982.

12) Tseng, S. C. G., Jarvinen, M. J., Nelson, W. G., Huang, J. -W., Woodcock-Mitchell, J. and Sun, T. -T. : Correlation of specific keratins with different types of epithelial differentiation: Monoclonal antibody study. Cell 30 : 361-372, 1982.

13) Eichner, R., Bonitz, P. and Sun, T. -T. : Classification of epidermal keratins according to their immunoreactivity, isoelectric point and mode of expression. J. Cell Biol. 98 : 1388-1396, 1984.

14) W oodcock-Mitchell, J., Eichner, R., Nelson, W. G. and Sun, T. -T. : Immunolocalization of keratin polypeptides in human epidermis using monoclonal antibodies. J. Cell Biol. 95 : 580-588, 1982.

15) Skerrow, D. and Skerrow, C. J. : Tonofilament differentiation in human epidermis, isolation and polypeptide chain composition of keratinocyte subpopulations. Exp. Cell Res. 143 : 27-35, 1983.

16) Bowden, P. E., Quinlan, R. A., Breitkreutz, D. and Fusenig, N. E. : Proteolytic modification of acidic and basic keratins during terminal differentiation of mouse and human epidermis. Eur. J. Biochem. 142:29-36, 1984.

17) Knapp, B., Rentrop, M., Schweitzer, J. and Winter, H. : Nonepidermal members of the keratin multigene family: cDNA sequences and in situ localization of the mRNAs. Nucleic Acid Res. 14 : 751-753, 1986.

18) Murase, N., Fukui, S. and Mori, M. : Heterogeneity of keratin distribution in the oral mucosa and skin of mammals as determined using monoclonal antibodies. Histochemistry $85: 265-276,1986$.

19) Rentrop, M., Knapp, B., Winter, H. and Schweitzer, J.: Differential localization of distinct keratin mRNA-species in mouse tongue epithelium by in situ hybridization with specific cDNA probes. J. Cell Biol. 103 : 2583-2591, 1986.

20) Juhl, M., Reibel, J. and Stoltze, K. : Immunohistochemical distribution of keratin proteins in clinically healthy human gingival epithelia. Scand. J. Dent. Res. 97 : 159-170, 1989.

21) Suzuki, Y. and Takeda, M.: Filaments in the cells of frog taste organ. Zool. Sci. 6 : 487-497, 1989.

22) Gibbins, J. R.: An electron microscopic study of the normal epithelium of the palate of the albino rat. Arch Oral Biol. 7 : 287295, 1962.

23) Zelickson, A. S. and Hartmann, J. F. : An electron microscope study of normal human non-keratinizing oral mucosa. J. Invest. Derm. 38 : 99-106, 1962.

24) Schroeder, H. E. and Theilade, J.: Elecron microscopy of normal human gingival epithelium. J. Periodont. Res. 1 : 95-119, 1966.

25）雪野莞爾：ラッテ舌粘膜上皮の微細構造と角化 について．札幌医誌 $31: 243-271 ， 1967$. 
26) Squier, C. A. : Ultrastructural observation on the keratinization process in rat buccal epithelium. Arch Oral Biol. 13 : 1445-1451, 1968.

27) Farbman, A. I. : The dual pattern of keratinization in filiform papillae on rat tongue. J. Anat. $106: 233-242,1970$.

28) Martinez, I. R. : The ultrastructure of the keratinizing epithelia of the incisor and molar gingivae of the albino rat: Similarities and differences. Anat. Rec. $170: 1-30,1970$.

29) Weinstock, M. and Wilgram, G. F. : Finestructural observations on the formation and enzymatic activity of keratinosomes in mouse tongue filiform papillae. J. Ultrastruct. Res. 30 : 262-274, 1970.

30) Appleton, J. and Tyldesley, W. R. : Observations on the ultrastructure of the buccal epithelium of the rat. Arch Oral Biol. 16 : 1071-1088, 1971.

31) Hayward, A. F., Hamilton, A. I. and Hackemann, M. M. A. : Histological and ultrastructural observations on the keratinizing epithelia of the palate of the rat. Arch Oral Biol. 18 : 1041-1057, 1973.

32) Kempson, S. A.: Ultrastructural observations on the keratohyalin granules of the rat oral epithelium. Arch Oral Biol. 19 : 10111024, 1974.

33）小田島哲世, 賀来 享: 実験的八ムスタ一舌癌 形成過程の超微形態学的研究. I . 正常舌粘膜 上皮の超微構造 ; 特に角化について，札幌医誌 47: 225-243, 1978.

34) Takeda, M., Obara, N. and Suzuki, Y. : Intermediate filaments in mouse taste bud cells. Arch. Histol. Cytol. 51 : 99-108. 1988.

35）武田正子, 小原伸子, 鈴木裕子：有郭乳頭上皮 細胞のケラチンフィラメント。東日本歯誌 7: 1-10, 1988.

36) Takeda, M., Obara, N. and Suzuki, Y. : Keratin filaments of epithelial and taste bud cells in the circumvallate papillae of adult and developing mice. Cell Tissue Res. 260 : 41-48, 1990.
37) Brody, I.: The ultrastructure of the tonofibrils in the keratinization process of normal human epidermis. J. Ultrastuct. Res. 4: 264-297, 1960.

38) Cane, A. K. and Spearman, R. I. C. : The keratinized epithelium of the house mouse (Mus Musculus) tongue: Its structure and histochemistry. Archs oral Biol. $14: 829-841$, 1969.

39) Steinert, P. M., Zimmerman, S. B., Starger, J. M. and Goldman, R. D. : Ten-nanometer filaments of hamster BHK-21 cells and epidermal keratin filaments have similar structures. Proc. Natl. Acad. Sci. USA. 75: 6098-6101, 1978.

40) Fuchs, E. and Marchuk, D. : Type I and type II keratins have evolved from lower eucaryotes to form the epidermal intermediate filaments in mammalian skin. Proc. Natl. Acad. Sci. USA $80: 5857-5861,1983$.

41) Steinert, P. M., Parry, D. A. D., Racoosin, E. L., Idler, W. W., Steven, A. C., Trus, B. L. and Roop, D. R.: The complete cDNA and deduced amino acid sequence of a type II mouse epidermal keratin of 60,000 $\mathrm{Da}$ : Analysis of sequence differences between type I and type II keratins. Proc. Natl. Acad. Sci. USA 81 : 5709-5713, 1984.

42) Fuchs, E., Tyner, A. L., Giudice, G. J., Marchuk, D., RayChaudhury, A. and Rosenberg, M.: The human keratin genes and their differential expression. Curr. Top. Dev. Biol. 22 : 5-34, 1987.

43) Steinert. P. M., Idler, W. W., Zhou, X. M., Johnson, L. D., Parry, D. A. D., Steven, A. C. and Roop, D. R. : Structural and functional implications of amino acid sequences of keratin intermediate filament subunits. Ann. N. Y. Acad. Sci. 455:451461, 1985.

44) Dale, B. A., Resing, K. A. and LonsdaleEccles, J. D.: Fillagrin: A keratin filament associated protein. Ann. N. Y. Acad. Sci. 455 : 330-342, 1985. 